\title{
Improving Topical Non-Melanoma Skin Cancer Treatment: In vitro Efficacy of a Novel Guanosine-Analog Phosphonate
}

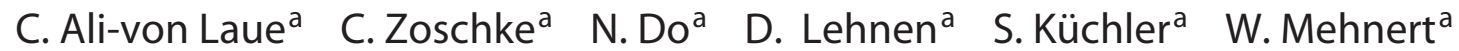 \\ T. Blaschke $^{b}$ K.D. Kramer ${ }^{b} \quad$ J.Plendl ${ }^{c} \quad$ G. Weindl ${ }^{a} \quad$ H.C. Korting ${ }^{d}$ \\ D. Hoeller Obrigkeit ${ }^{\mathrm{e}} \quad$ H.-F. Merk ${ }^{\mathrm{e}} \quad$ M. Schäfer-Korting ${ }^{\mathrm{a}}$
}

${ }^{a}$ Institute for Pharmacy, ${ }^{b}$ Department of Physics, and ${ }^{\mathrm{C}}$ Institute of Veterinary Anatomy, Freie Universität Berlin, Berlin, ${ }^{\mathrm{d} C l i n i c}$ for Dermatology and Allergology, Ludwig-Maximilians-Universität, Munich, and ${ }^{\mathrm{e}}$ Department of Dermatology and Allergology, University Hospital RWTH Aachen, Aachen, Germany

\section{Key Words}

Drug delivery systems $\cdot$ Keratin-18 $\cdot$ Preclinical drug development . Purine nucleotide analogues - Tissue engineering $\cdot$ Topical administration $\cdot$ Non-melanoma skin cancer

\begin{abstract}
Actinic keratosis, a frequent carcinoma in situ of non-melanoma skin cancer (NMSC), can transform into life-threatening cutaneous squamous cell carcinoma. Current treatment is limited due to low complete clearance rates and asks for novel therapeutic concepts; the novel purine nucleotide analogue OxBu may be an option. In order to enhance skin penetration, solid lipid nanoparticles (SLN, 136-156 nm) were produced with an OxBu entrapment efficiency of $96.5 \pm$ $0.1 \%$. For improved preclinical evaluation, we combined tissue engineering with clinically used keratin-18 quantification. Three doses of $10^{-3} \mathrm{~mol} / / \mathrm{O} \mathrm{OBu}$, dissolved in phosphatebuffered saline as well as loaded to SLN, were effective on reconstructed NMSC. Tumour response and apoptosis induction were evaluated by an increase in caspase-cleaved fragment of keratin-18, caspase-7 activation as well as by reduced expression of matrix metallopeptidase-2 and Ki-67.
\end{abstract}

\section{KARGER}

(c) 2014 S. Karger AG, Basel

$1660-5527 / 14 / 0274-0173 \$ 39.50 / 0$

E-Mail karger@karger.com

www.karger.com/spp
OxBu efficacy was superior to equimolar 5 -fluorouracil solution, and thus the drug should be subjected to the next step in preclinical evaluation.

(c) 2014 S. Karger AG, Basel

\section{Introduction}

Actinic keratosis is the carcinoma in situ of cutaneous squamous cell carcinoma (cSCC), a non-melanoma skin cancer (NMSC). Being associated with a papillomavirus infection and frequent exposure to the sun, prevalence is $6-25 \%$ in western populations and up to $60 \%$ in Australia [1]. Up to $20 \%$ of untreated actinic keratosis lesions develop into malignant cSCC, and up to $82 \%$ of invasive cSCC arise close to actinic keratosis lesions [2]. Since the prediction of carcinoma transformation to the invasive disease is not feasible, elimination of the lesions by field pharmacotherapy in the premalignant actinic keratosis stage is highly recommended [3]. Yet, current treatment options are either not sufficiently effective or very painful

\section{C.A.-v.L. and C.Z. contributed equally to this work.}


or both, and thus cSCC has become a most prevalent lethal risk factor in heart and kidney transplant recipients [4]. Complete cure rates in large-size clinical studies are less than $70 \%$ with 5-fluoruracil (5-FU), diclofenac/hyaluronic acid [3], imiquimod [5] and photodynamic therapy using 5-aminolaevulinic acid followed by red light irradiation. Response rates are up to $91 \%$ when using methyl 5-aminolaevulinate as photosensitizer for minor to moderate lesions [6]. Although the ingenol mebutate efficacy in larger multicentre trials is even lower (34-42\% [7]), the outcome looks promising with respect to the short-course treatment. In a 12-month follow-up study of ingenol mebutate, sustained clearance was maximally 46\% [8].

We addressed the unmet clinical need of effective NMSC field therapy by developing a set of DNA polymerase inhibitors by molecular modelling and ligand docking using antiviral agents as a starting point $[9,10]$. Several compounds inhibited the proliferation of SCC cell lines clearly more effectively than of normal human keratinocytes [11]. In-depth, preclinical evaluation of the most selectively acting compound $\mathrm{OxBu}$ was the primary goal of the present study. Since the predictive value of animal-generated pharmacological data for humans is low (70\% [12]), we decided on an advanced human-cellbased NMSC model using a set of biomarkers for readout. This includes the caspase-cleaved fragment of keratin-18 (ccK18) and total keratin-18 (tK18) being used to evaluate drug-induced apoptosis in patients $[13,14]$.

The second goal of the present study was to investigate the potential surplus value of solid lipid nanoparticles (SLN) for topical treatment with $\mathrm{OxBu}$. The molecular size of the guanosine-analog phosphonate $\mathrm{OxBu}$ exceeds $400 \mathrm{~g} / \mathrm{mol}$ [11] which is not optimal for topical therapy [15], in particular when aiming for the use in hyperkeratotic skin. Moreover, $5 \mathrm{H}$ bond acceptors are at the cutting edge of cutaneous absorbability [16]. Thus, penetration enhancement by drug loading to an efficient carrier system may be an option. SLN can provide high drug encapsulation capacity, protect labile compounds, ensure longterm physical stability, improve bioavailability [17] and can restrict systemic toxicity through limited access of the agent to blood vessels [18-20].

\section{Materials and Methods}

\section{Materials}

$\mathrm{OxBu}(\mathrm{MW} 436.4 \mathrm{~g} / \mathrm{mol}, \log \mathrm{P} 1.36$ ) was synthesized [11] by Chiracon (Luckenwalde, Germany). 5-FU (MW $130.1 \mathrm{~g} / \mathrm{mol}, \log \mathrm{P}$ -0.91 ) and Nile red (MW $318.4 \mathrm{~g} / \mathrm{mol}, \log \mathrm{P} 3.10$ ) were supplied by Sigma-Aldrich (Munich, Germany). OxBu was dissolved in di- methylsulphoxide (DMSO; BASF, Ludwigshafen, Germany), 5-FU in double-distilled water. Stock solutions were diluted with phosphate-buffered saline, $\mathrm{pH} 7.4$ (PBS). OxBu SLN were made of 3.5\% glyceryl behenate (Compritol ${ }^{\circledR} 888$ ATO, Gattefossé, Saint-Priest, France) and poloxamer 188 (Lutrol ${ }^{\circledR}$ F 68; BASF). All other chemicals were of the highest purity available.

\section{Construction and Characterization of the in vitro NMSC}

Model

Normal fibroblasts and keratinocytes were isolated from human juvenile foreskin and cultured as described elsewhere [21]. For model building cells were pooled from 3 donors. In vitro organotypic NMSC constructs were built based on the cSCC model described previously [22]. We adapted keratinocyte, fibroblast and tumour cell seeding to grow actinic keratosis like constructs with SCC -12 cells (donated by Howard Green, Dana Farber Institute, Boston, Mass., USA) forming nests only in the epidermis. The constructs were made from human dermal fibroblasts embedded in collagen G ( $\geq 95 \%$ collagen I; Biochrom, Berlin, Germany) forming the dermis equivalent $\left(1 \times 10^{6}\right.$ fibroblasts, 1 st to 3 rd passage $)$. Normal human keratinocytes $\left(2 \times 10^{6}\right.$ keratinocytes, 2 nd to 3 rd passage) were seeded onto of the dermal equivalent next day. The constructs were cultivated and raised to air-liquid interface on day 7 . Tumour was induced on day 12 by seeding SCC- 12 cells $\left(2 \times 10^{4}\right.$ cells, passage $<100$ ) onto the construct which was cultivated for another 8 days with change of medium 3 times a week (fig. 1a). The use of deep-well plates (BD Biosciences, Franklin Lakes, N.J., USA) ensured sustenance and increased reproducibility.

The histological quality of the construct on day 20 was evaluated by haematoxylin and eosin staining of $5 \mu \mathrm{m}$ paraffin-embedded slices. EZ-DeWax ${ }^{\mathrm{TM}}$ solution (BioGenex, San Ramon, Calif., USA) was used to remove paraffin (Thermo Scientific, Braunschweig, Germany) from slices. To elucidate the tumour localization SCC-12 cells were stained with CellTracker ${ }^{\mathrm{TM}}$ Red CMTPX (Invitrogen Molecular Probes, Eugene, Oreg., USA) according to the manufacturer's instructions before seeding.

\section{OxBu Efficacy on the in vitro NMSC Model}

The drug formulations $\left(10^{-3} \mathrm{~mol} / \mathrm{l}\right)$ were applied $\left(10 \mu \mathrm{l} / \mathrm{cm}^{2}\right)$ on the surface of the NMSC constructs. For a 7-day treatment regimen 3 applications in total were combined with medium changes on days 14, 16 and 18 (fig. 1a); on day 18, effects were also evaluated following 2 doses. The formulations were $\mathrm{OxBu}$ solution, $\mathrm{OxBu}$ SLN dispersion and 5-FU solution. Unloaded SLN and respective solvents served as control.

Proliferation, apoptosis and tumour invasion in the NMSC model were investigated by immunofluorescence staining according to routine histological protocols. Primary antibodies directed to proliferation-up-regulated Ki-67, apoptosis-induced caspase-7 and invasion-facilitating matrix metallopeptidase-2 (MMP-2) were used with fluorescence-labelled secondary antibodies. Primary and secondary antibodies were supplied by Abcam (Cambridge, UK). 4',6-Diamidino-2-phenylindole (Dianova, Hamburg, Germany) served for nuclei staining. Pictures of immunofluorescence staining, taken with a fluorescence microscope (BZ-8000; Keyence, Neu-Isenburg, Germany), were analysed in an observerblind fashion by at least 3 experienced researchers.

Apoptosis was quantified by ccK18 release. Culture medium $(1 \mathrm{ml})$ was collected repeatedly over time (fig. 1a) and centrifuged at $2,400 \mathrm{~g}$ and $4^{\circ} \mathrm{C}$ for $2 \mathrm{~min}$. To differentiate between cell death 

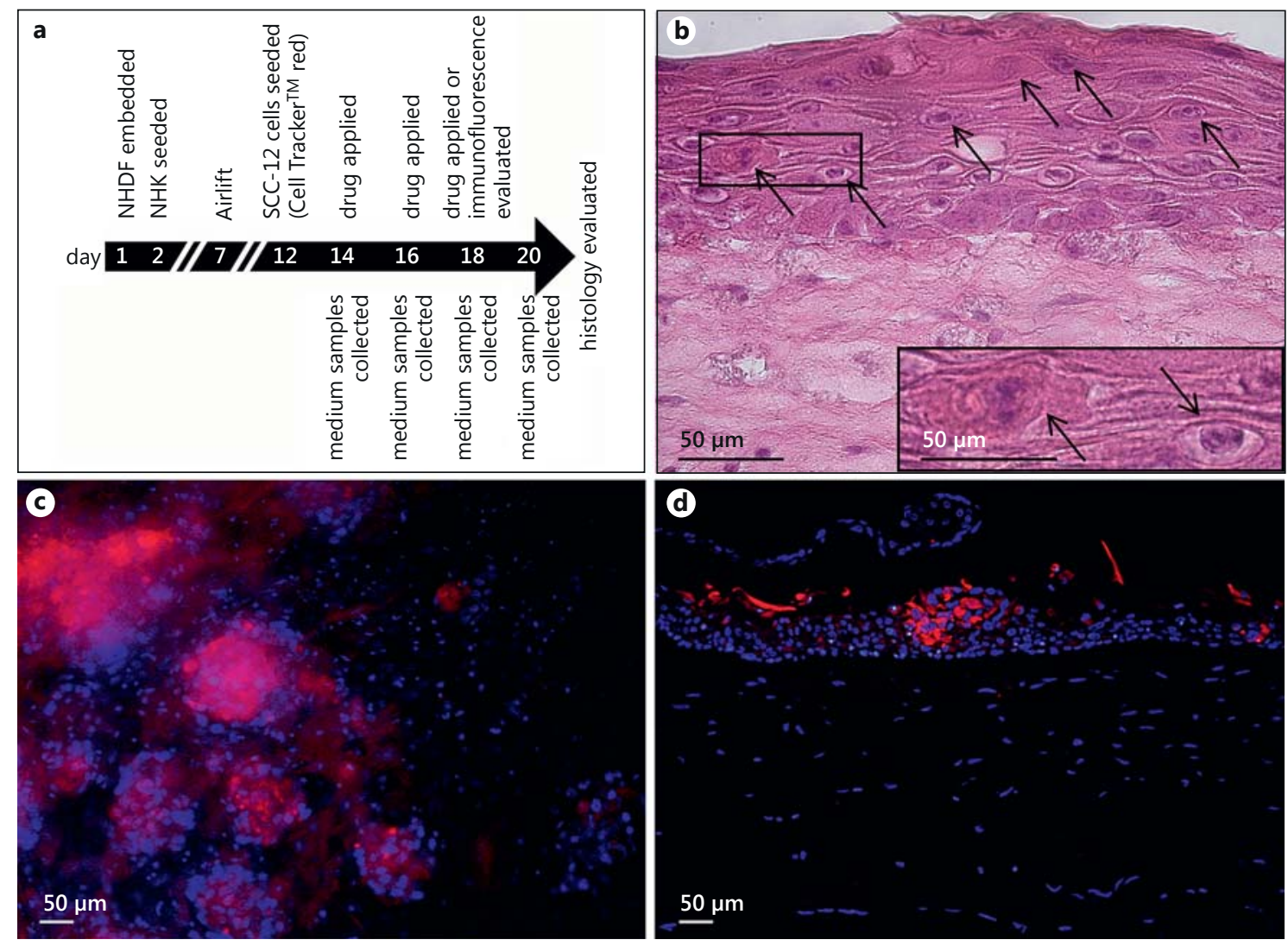

Fig. 1. a Procedure outline. NHDF $=$ Normal human dermal fibroblasts; NHK $=$ normal human keratinocytes . b Haematoxylin- and eosin-stained cross-section of the full-thickness human skin model with transformed and normal keratinocytes side by side; arrows indicate the tumour cells. The inset shows dysplastic tumour cells with atypical, enlarged, irregular and hyperchromatic nuclei. c, d NMSC model stained with 4',6-diamidino-2-phenylindole (nuclei) and CellTracker Red CMPTX (SCC-12 cells): aerial view of the separated epidermis (c) and cross-section of the NMSC model (d). Constructs with stained SCC-12 cells were not used for OxBu evaluation. Representative pictures of 7 batches. Magnification $\times 30$ (b), $\times 60$ (b, inset), $\times 10$ (c, d).

modes, we combined M30 Apoptosense ${ }^{\circledR}$ with an M65 ${ }^{\circledR}$ ELISA kit, both obtained from Peviva (Bromma, Sweden). Analysis was performed according to the manufacturer's instructions. For dose determination, tumour cell cytotoxicity of $\mathrm{OxBu}$ was analysed using the methylthiazolyldiphenyltetrazolium bromide (MTT) dye reduction assay for SCC-12 monolayers [11].

\section{SLN Preparation and Characterization}

$\mathrm{OxBu}$ SLN were prepared using the hot homogenization method $[17,23,24]$ with the modification of drug dissolution in DMSO. In short, OxBu dissolved in DMSO was mixed with melted glyceryl behenate. The aqueous phase with $2.5 \%$ poloxamer 188 was added and then dispersed using a rotor-stator mixer for $30 \mathrm{~s}$ at 9,500 rpm. The pre-emulsion was homogenized applying a pressure of 500 bar (EmulsiFlex-C5; Avestin, Ottawa, Ont., Canada) in 3 homogenization cycles. The product, containing 5\% DMSO, was collected in silanized glass vials and cooled down in a $15^{\circ} \mathrm{C}$ water bath.

SLN stability was assessed for at least 3 months with respect to lipid concentration $(2.5,3.5,5.0 \%, \mathrm{w} / \mathrm{w}$, glyceryl behenate) and storage temperature $\left(5,25,40^{\circ} \mathrm{C}\right)$. Particle size and size distribution (polydispersity index) were determined by photon correlation spectroscopy (PCS; Zetasizer Nano ZS, Malvern Instruments, Malvern, UK). Applying laser diffractometry (Mastersizer 2000; Malvern Instruments), $\mathrm{LD}_{95}$ values were determined, too. $95 \%$ of the particles were smaller than the stated $\mathrm{LD}_{95}$ size. To detect drug crystals exceeding $1 \mu \mathrm{m}$, light microscopy was used. In addition, scanning electron microscopy (Zeiss DSM 950 microscope; Zeiss, Jena, Germany) images were generated to study size and shape of the nanocarriers. Parelectric spectroscopy was employed to check for free drug molecules in the aqueous phase and to unravel the mode of $\mathrm{OxBu}$ interaction with the lipid matrix $[23,25]$. The amount of OxBu loaded to SLN (drug entrapment efficiency [17]) was quantified from the supernatant of centrifuged nanocarriers $(70,000 \mathrm{~g}, 90$ min) by high-performance liquid chromatography (HPLC).

Aiming for a ready-to-use formulation, 2 hydrogels were prepared. For the conventional gel $(\mathrm{pH} 8) \mathrm{OxBu}$ solution $(0.1 \mathrm{~mol} / \mathrm{l}$ in $\mathrm{NaOH}$ ) was added to $250 \mathrm{mg}$ hydroxyethylcellulose (HEC 10,000; Hoechst, Frankfurt/Main, Germany), dispersed in 1 g $86 \%$ glycerol and subsequently filled up with PBS. For gel-incorporated 
SLN, 250 mg HEC 10,000 were dispersed in $1 \mathrm{~g} 86 \%$ glycerol and subsequently filled up with $\mathrm{OxBu}$ SLN dispersion. Both gels contained $\mathrm{OxBu}$ at a concentration of $10^{-3} \mathrm{~mol} / \mathrm{l}$.

In order to study the effect of DMSO on skin penetration of an SLN-loaded drug, we loaded SLN with the probe Nile red (0.004\%) using either glyceryl behenate (5 and $10 \%$ ) without DMSO [26] or glyceryl behenate (5\%) with DMSO (5\%) for particle formulation as described above. Incorporation of Nile red into the lipid matrix was assured by parelectric spectroscopy. The penetration of Nile red-loaded SLN was studied in cryoconserved human female skin ex vivo (aged 39-54 years, $\mathrm{n}=3$ donors; with permission) according to a validated test protocol $[26,27]$.

\section{HPLC/OxBu Release}

$\mathrm{OxBu}$ concentrations were quantified by HPLC (Merck Hitachi, Tokyo, Japan, equipped with a ternary L-6200 pump, AS-2000A autosampler, D 6000 interface). The stationary phase was a Luna Pheny Hexyl $4.6 \times 150 \mathrm{~mm}(5 \mu \mathrm{m}$ packing) column and a $4 \times 3 \mathrm{~mm}$ guard column (Phenomenex, Aschaffenburg, Germany). The mobile phase was sodium phosphate buffer ( $\mathrm{pH} 7.5$, $25 \mathrm{mmol} / \mathrm{l})$ :acetonitrile (77:23, $1.5 \mathrm{ml} / \mathrm{min}$ isocratic flow rate). For quantification an L-4000A UV detector (Merck Hitachi) was operated at $276 \mathrm{~nm}$. The retention time of $\mathrm{OxBu}$ was $4.8 \mathrm{~min}$. The method was validated referring to ICH Q2B [28]. Linearity was proven for OxBu $5 \times 10^{-7}$ to $10^{-4} \mathrm{~mol} / \mathrm{l}\left(\mathrm{r}^{2}>0.99\right)$. The lower limit of detection $(3 \times$ signal-to-noise ratio $)$ and lower limit of quantification $\left(10 \times\right.$ signal-to-noise ratio) were $2 \times 10^{-7}$ and $5 \times 10^{-7} \mathrm{~mol} / \mathrm{l}$, respectively. Recovery from PBS was $96-102 \%$. Precision of interand intraday measurements was $<7 \%$ relative standard deviation.

The release rates of $\mathrm{OxBu}$ from formulations were studied as described [26], and the rate of OxBu release from formulations was calculated based on $\mathrm{OxBu}$ amounts in the acceptor fluid according to Higuchi [29].

\section{Statistical Analysis}

All experiments were performed at least in duplicate; results were expressed as arithmetic mean values \pm standard error of the mean (SEM). Explorative data analysis was done using the MannWhitney test for OxBu efficacy and the Kruskal-Wallis test for $\mathrm{OxBu}$ release followed by Dunn's multiple comparison test. $\mathrm{p} \leq$ 0.05 was considered to indicate a statistically significant difference.

\section{Results and Discussion}

\section{OxBu Efficacy on the in vitro NMSC Model}

Initial studies in monolayer cultures indicated high $\mathrm{OxBu}$ efficacy and a selective effect on transformed keratinocytes [11]. The next step in the preclinical OxBu evaluation was testing in a disease model. Among organotypic human-cell based NMSC models, basically 3 approaches are competing: the use of patient xenografts, tumour cell lines only seeded onto a dermal equivalent [30] and cocultures of human primary normal cells with tumour cell lines [22]. As access to patient xenografts is limited, we opted for the coculture model already vali- dated for preclinical treatment evaluation based on a study of photodynamic therapy [22]. Tissue culturing was however modified to reconstruct actinic keratosis. Normal skin models, built for control, showed a multilayered viable epidermis with an intact basal membrane zone and regularly distributed fibroblasts in the dermal equivalent. Within NMSC constructs SCC-12 nests spread across the epidermis (fig. 1b-d). SCC-12 cells exhibit a dysplastic histology; nuclei are atypical, enlarged, irregular and hyperchromatic. Since no tumour cells were found in the dermal equivalent, we reconstructed actinic keratosis, the carcinoma in situ of invasive and metastatic cSCC. CellTracker Red CMTPX [31] proved to be useful to trace non-invasively tumour cells over time. To ensure that SCC-12 cells keep the fluorescent dye over 9 days, we stained SCC-12 monolayers for the same period. Model construction, performed according to an in-house standard operating procedure, was highly reproducible as derived from histology evaluation of 7 batches.

Considering maximal skin penetration of only a few percent [15] and SCC-12 cell viability reduction to $61 \pm$ $12 \% 48 \mathrm{~h}$ after $\mathrm{OxBu}\left(10^{-4} \mathrm{~mol} / \mathrm{l}\right)$ application (MTT assay, $\mathrm{n}=3$, mean $\pm \mathrm{SEM})$, the effect of $\mathrm{OxBu}\left(10^{-3} \mathrm{~mol} / \mathrm{l}\right)$ on reconstructed NMSC was compared to the current firstline NMSC treatment 5-FU $[10,11]$. The comparator dose (5-FU, $10^{-3} \mathrm{~mol} / \mathrm{l}$ ) was chosen balancing lower 5-FU potency, $\mathrm{IC}_{50}(5-\mathrm{FU})=9.8 \times 10^{-7} \mathrm{~mol} / \mathrm{l}$ compared to $\mathrm{IC}_{50}(\mathrm{OxBu})=3.7 \times 10^{-10} \mathrm{~mol} / 1$ [11], in SCC cell monolayers and its physicochemical properties, which should favour skin penetration.

Immunofluorescence analysis revealed increased caspase-7 staining for $\mathrm{OxBu}$ and 5-FU solution compared to the respective solvent controls. The pro-apoptotic effect of $\mathrm{OxBu}$ slightly surmounted the effect of 5-FU whereas (almost) no caspase-7 activity was detected in the solvent controls. Cell proliferation (Ki-67 staining) decreased following $\mathrm{OxBu}$ and 5-FU application compared to solvent controls. Interestingly, only $\mathrm{OxBu}$ solution reduced the expression of MMP-2, indicating less invasive cancerous lesions. Neither solvent controls nor 5-FU solution showed this effect (fig. 2).

Although immunofluorescence analysis allows a detailed histological evaluation, this method entails some deficiencies. Samples cannot be taken from the same construct before and after treatment, robustness to experimental conditions is low and quantification is poorly standardized. This can be overcome by making use of keratin-18 as biomarker. During apoptosis, e.g. induced by chemotherapy, caspases cleave tK18, and ccK18 is released from cytosol within $48 \mathrm{~h}$. Plasma and tissue levels 


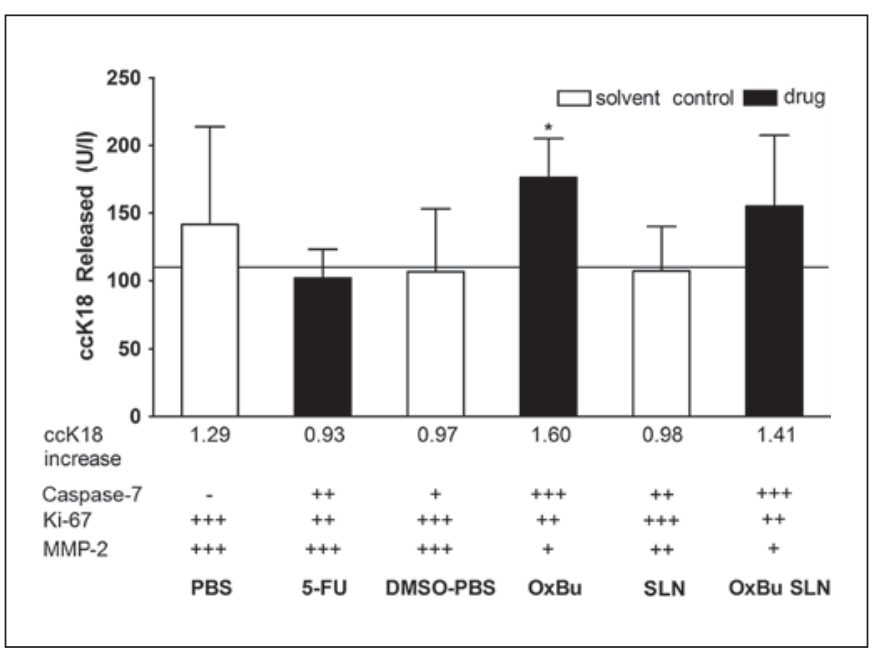

Fig. 2. OxBu efficacy in the NMSC model. ccK18 release on day 20 after 3 applications of the test formulations (black columns, $10^{-3}$ $\mathrm{mol} / \mathrm{l}, 10 \mu \mathrm{l} / \mathrm{cm}^{2}$ epidermis) or respective controls (white columns); the line at $110 \mathrm{U} / \mathrm{l}$ depicts ccK18 release on day 14 before treatment. Visual evaluation of immunofluorescence staining was made on day 18 after 2 applications of the test formulations or respective controls. Strong $(+++)$, moderate $(++)$, weak $(+)$ or missing $(-)$ presence of the respective antigen was evaluated in an observerblind fashion by at least 3 experienced researchers. Controls were PBS for 5-fluorouracil, DMSO-PBS for OxBu and unloaded SLN for OxBu SLN. The SLN were made of 3.5\% glyceryl behenate and $5 \%$ DMSO. The $n$-fold increases were calculated as day 20/day 14 ratios. Constructs were from 3 to 5 batches, mean \pm SEM, ${ }^{*} \mathrm{p}<0.05$.

of ccK18 and tK18 in tumour patients exceed those in healthy persons $[13,14,32,33]$. High ccK18 plasma levels are correlated with poor prognoses of epithelial cell-associated carcinomas, melanoma and different types of SCC [32-34]. Elevated ccK18/tK18 ratios and elevated ccK18 release after treatment indicate apoptosis induction and tumour response $[13,14]$. To evaluate the fraction of apoptosis in our NMSC model, we quantified pre- and posttreatment ccK18 (fig. 2) and tK18 (not shown) release in medium and calculated the ccK18 increase and ccK18/ tCK18 ratio. This approach follows clinical investigations $[14,32,35]$.

We observed the highest increase in apoptosis among all formulations with $\mathrm{OxBu}$ solution (1.60-fold increase, $\mathrm{p}<0.05)$. 5-FU (0.93-fold increase) did not enhance ccK18 release. Comparing posttreatment ccK18/tK18 ratios, $\mathrm{OxBu}(0.58)$ shows a higher ratio than 5 -FU (0.49) and solvent controls (0.36-0.41). Thus, the antitumour effect of $\mathrm{OxBu}$ is clearly indicated by both immunofluorescence and ccK18 release.

In vitro Efficacy of a Novel Guanosine Phosphonate Analogue
Table 1. Stability of OxBu SLN and unloaded SLN

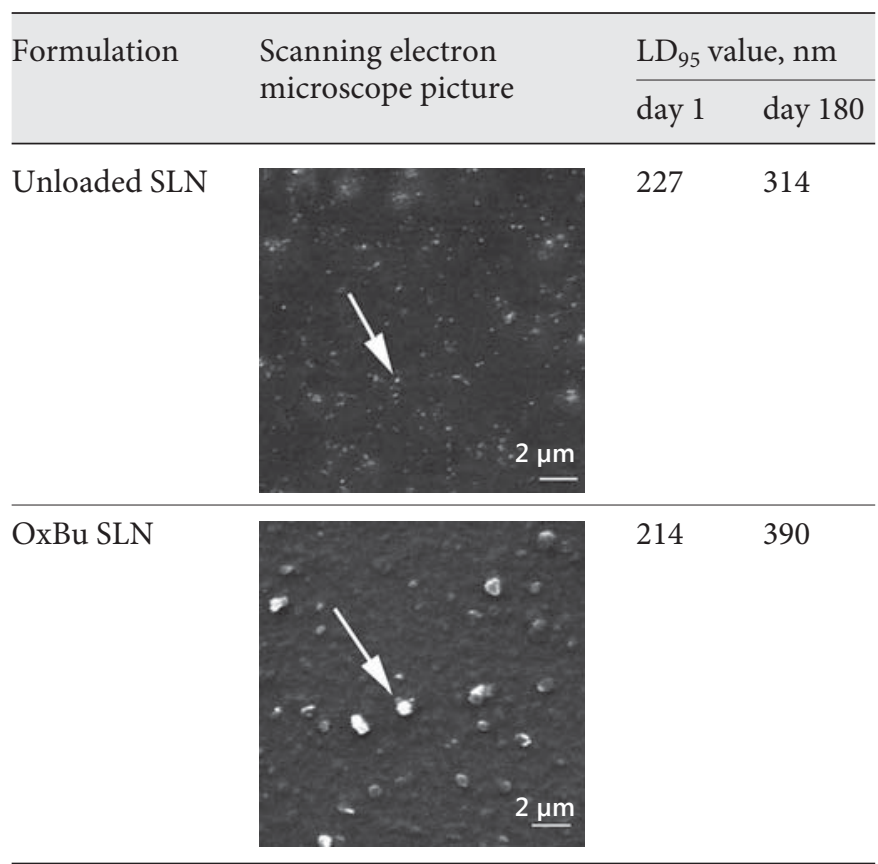

SLN made of 3.5\% glyceryl behenate, 5\% DMSO and sputtered with a gold layer of $45 \mathrm{~nm}$ on scanning electron microscope pictures. Storage at $5^{\circ} \mathrm{C}$.

In conclusion, combining immunofluorescence staining of MMP-2, Ki-67 and caspase-7 [22, 30] with ccK18 release data [13] for efficacy read-out on NMSC constructs can offer an approach to a predictive preclinical drug evaluation. To the best of our knowledge, this approach has not been used before.

\section{OxBu Solid Lipid Nanoparticles}

Next, we developed OxBu SLN to ensure high drug levels in the target layers. Particle sizes of OxBu SLN $\left[\mathrm{c}(\mathrm{OxBu})=10^{-3} \mathrm{~mol} / \mathrm{l}\right]$, composed of glyceryl behenate and DMSO, were 136-156 nm (PCS) with narrow size distribution (polydispersity index $=0.2$ ) the day after production. Scanning electron microscopy demonstrated regular shape and relatively homogenous size, too (table 1). Particle aggregates or drug crystals were not detected by optical and scanning electron microscopy. Drug entrapment efficiency was $96.5 \pm 0.1 \%$.

Parelectric spectroscopy was employed to study $\mathrm{OxBu}$ interaction with the lipid matrix. The dipole mobility $\mathrm{f}_{0}$ remained stable at around $0.4 \mathrm{MHz}$, the dipole density $\Delta \varepsilon$ increased from 269 to 468 . Thus, OxBu molecules were either completely incorporated into the lipid matrix or

Skin Pharmacol Physiol 2014;27:173-180 177 


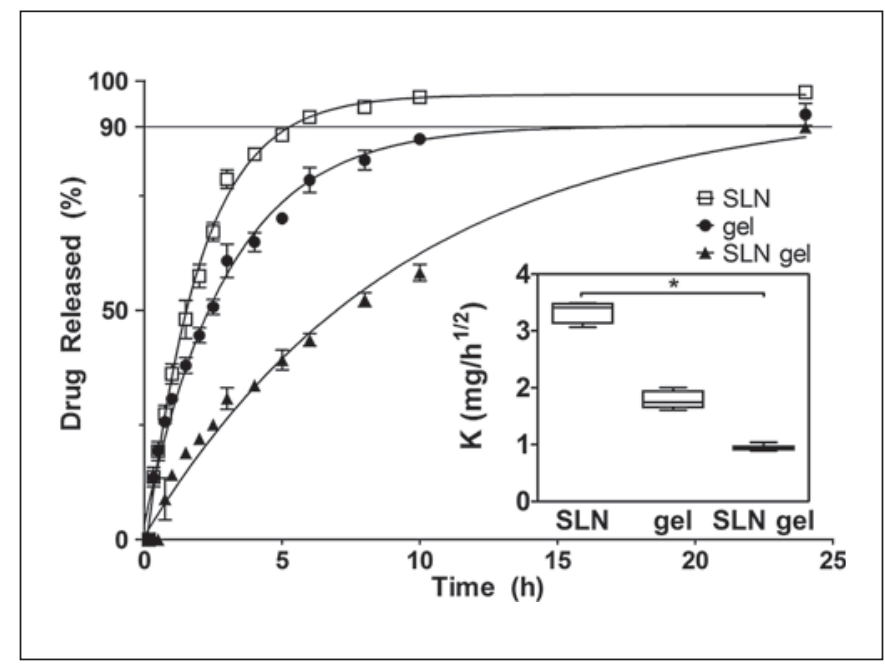

Fig. 3. Cumulative amount of $\mathrm{OxBu}$ released from SLN dispersion, gel (HEC gel) and SLN gel (gel-embedded SLN). Mean \pm SEM, $\mathrm{n}=3$, SLN made of 3.5\% glyceryl behenate and 5\% DMSO. The inset shows the $\mathrm{OxBu}$ release rate $\mathrm{K}$ derived from the Higuchi plot $[\mathrm{Q}(\mathrm{t})=\mathrm{K} \cdot \sqrt{ } \mathrm{t}]$, minimum to maximum, line at mean, $\mathrm{n}=6,{ }^{*} \mathrm{p}<$ 0.05 .

free in solution, but not attached to the surface. Yet, almost complete drug entrapment and additional parelectric spectroscopy measurements at high frequencies excluded $\mathrm{OxBu}$ molecules free in solution. In contrast to $\mathrm{OxBu}$ embedded into the lipid matrix, glucocorticoids tend to attach to the surface of the lipid matrix of the SLN [36]. The difference can be due to the addition of DMSO for $\mathrm{OxBu}$ SLN formation.

$\mathrm{OxBu}$ SLN sizes as well as size distributions increased concomitantly with higher lipid concentrations [2.5\% (w/w) glyceryl behenate: $245 \mathrm{~nm}, 3.5 \%: 326 \mathrm{~nm}, 5.0 \%: 378$ $\mathrm{nm}$; PCS, storage at $5^{\circ} \mathrm{C}$ ] within 6 months. Particle aggregation $[5 \%(\mathrm{w} / \mathrm{w})$ glyceryl behenate] occurred due to incomplete coverage of lipid particle surface by surfactant molecules [24], too. Increased storage temperature (25, $40^{\circ} \mathrm{C}$ ) destabilized the OxBu SLN dispersion leading to higher nanodispersion viscosity and finally to gelation. Physical instability at higher temperature was probably due to a decrease in the microviscosity of the surfactant and therefore a higher particle diffusion constant. Hence, the electrostatic repulsion between the particles can be easily overcome resulting in aggregation and gel formation [24]. However, the particle size of unloaded SLN remained rather stable at $25^{\circ} \mathrm{C}$, but $\mathrm{OxBu}$ SLN increased to $325 \mathrm{~nm}$ (PCS) with $3.5 \%$ glyceryl behenate and to $344 \mathrm{~nm}$ (PCS) with $2.5 \%$ glyceryl behenate.
To investigate the impact of DMSO on the cutaneous penetration of the SLN cargo, we opted for the wellknown dye Nile red instead of OxBu. Since DMSO is mandatory for loading OxBu to SLN, we cannot perform comparative penetration studies with or without DMSO. The penetration enhancer DMSO increased Nile red penetration into viable epidermis 1.7 -fold $(\mathrm{p}=0.07)$ when added to SLN [5\% (w/w) glyceryl behenate]. Nile red penetration from SLN (10\% [36]) was not significantly different (0.92-fold) from SLN (5\%).

In summary, OxBu SLN made of 3.5\% (w/w) glyceryl behenate and 5\% DMSO may have the potential to enhance skin penetration $[19,20]$.

\section{$\mathrm{OxBu}$ Release}

For a ready-to-use formulation we embedded $\mathrm{OxBu}$ SLN into HEC gel (SLN gel) which was generated by a single-step procedure, thus avoiding drug dilution. For efficient topical therapy the formulation must release $\mathrm{OxBu}$ sufficiently. $\mathrm{OxBu}$ release rates ( $\mathrm{K}$ values) from SLN, gel and SLN gel (fig. 3) were calculated plotting released drug as described by Higuchi [29]. The release rates of OxBu ranked SLN > gel $>$ SLN gel. The significantly prolonged release from SLN gel to SLN ( $p \leq 0.05$ ) can be explained by a slow diffusion of $\mathrm{OxBu}$ into the acceptor phase, as particle mobility is restricted by the gel matrix. In fact, testing SLN alone, OxBu concentrations in the acceptor fluid increased rather rapidly. $90 \%$ release was obtained after $5 \mathrm{~h}$ with the SLN, after $17 \mathrm{~h}$ with the gel and after $24 \mathrm{~h}$ with the SLN gel. The reference solution released $90 \%$ after $2.6 \mathrm{~h}$. Lag times (time for membrane saturation plus time for membrane penetration of the drug) were low $(\leq 0.11 \mathrm{~h})$. High $\mathrm{r}^{2}$ values $\left(\mathrm{r}^{2}>0.96\right)$ demonstrated data reproducibility. Although SLN gel is the most convenient $\mathrm{OxBu}$ formulation for the patient, we decided for the fluid SLN dispersion to focus on SLN effects on OxBu efficacy.

\section{SLN Surplus Value for Topical NMSC Treatment with $\mathrm{OxBu}$}

In the NMSC model OxBu SLN activated caspase-7 and inhibited expression of MMP-2 as well as of Ki-67 close to $\mathrm{OxBu}$ (fig. 2). ccK18 release, although it failed to be significant (fig. 2), and ccK18/tK18 ratio (0.76) substantiate a pro-apoptotic effect of OxBu SLN, too.

Considering the 1.41-fold increase in ccK18 release, SLN are slightly less pro-apoptotic compared to OxBu solution. This is in accordance with the recently published improvement of wound healing due to enhanced keratinocyte proliferation and migration $[37,38]$. In actinic 
keratosis this might be beneficial with respect to local tolerability of topical OxBu treatment.

In a subsequent study we will compare SLN gel to gel. A penetration-enhancing and irritation-limiting effect of glycerol [39] might add to the antitumour effect and improve local tolerability. Although a wide variety of nanocarriers is currently under investigation [40], SLN are favourable due to augmented penetration and proven safety.

\section{Conclusion}

The combination of human cell-based tissue engineering with clinically used keratin-18 and immunofluorescence offers an approach to preclinical evaluation of topical anticancer drugs while potentially reducing animal testing. The novel guanosine-analog phosphonate $\mathrm{OxBu}$, proving most active in the test, may be an innovative option for topical NMSC treatment. Topical OxBu formulations, with or without nanoparticles, should be further investigated in order to improve current disaffecting treatment options for NMSC field cancerization.

\section{Acknowledgement}

This work was financially supported by the German Ministry of Education and Research Nanoderm Project (13N9062). Christian Zoschke gratefully acknowledges a scholarship of the German National Academic Foundation (Studienstiftung des deutschen Volkes e.V.) and Dominika Lehnen of Dahlem Research School. The authors give thanks to Dr. Margitta Dathe, Leibniz Institute of Molecular Pharmacology, Berlin, Germany, for technical support with the ultracentrifugation method. The excellent technical assistance of Hannelore Gonska is highly appreciated.

\section{References}

1 Nashan D, Meiss F, Müller M: Therapeutic strategies for actinic keratoses - a systematic review. Eur J Dermatol 2013;23:14-32.

-2 Stockfleth E, Ferrandiz C, Grob JJ, Leigh I, Pehamberger $\mathrm{H}, \mathrm{Kerl} \mathrm{H}$ : Development of a treatment algorithm for actinic keratoses: a European consensus. Eur J Dermatol 2008; 18:651659.

3 Merk HF: Topical diclofenac in the treatment of actinic keratoses. Int J Dermatol 2007;46: 12-18.

4 Molina BD, Leiro MG, Pulpón LA, Mirabet S, Yanez JF, Bonet LA, Vilchez FG, Delgado JF, Manito N, Rábago G, Arizón JM, Romero N, Roig E, Blasco T, Pascual D, de la Fuente L, Muniz J: Incidence and risk factors for nonmelanoma skin cancer after heart transplantation. Transplant Proc 2010;42:3001-3005.

5 Hanke CW, Beer KR, Stockfleth E, Wu J, Rosen T, Levy S: Imiquimod 2.5 and $3.75 \%$ for the treatment of actinic keratoses: results of two placebo-controlled studies of daily application to the face and balding scalp for two 3-week cycles. J Am Acad Dermatol 2010;62: 573-581.

6 Szeimies RM, Radny P, Sebastian M, Borrosch F, Dirschka T, Krahn-Senftleben G, Reich K, Pabst G, Voss D, Foguet M, Gahlmann R, Lubbert H, Reinhold U: Photodynamic therapy with BF-200 ALA for the treatment of actinic keratosis: results of a prospective, randomized, double-blind, placebocontrolled phase III study. Br J Dermatol 2010;163:386-394.

7 Lebwohl M, Swanson N, Anderson LL, Melgaard A, Xu Z, Berman B: Ingenol mebutate gel for actinic keratosis. N Engl J Med 2012; 366:1010-1019.

\section{Lebwohl M, Shumack S, Gold LS, Melgaard A, Larsson T, Tyring SK: Long-term follow-up study of ingenol mebutate gel for the treat- ment of actinic keratoses. JAMA Dermatol 2013:1-5. \\ \9 Richartz A, Höltje M, Brandt B, Schäfer-Kor-} ting M, Höltje HD: Targeting human DNA polymerase alpha for the inhibition of keratinocyte proliferation. 1. Homology model, active site architecture and ligand binding. J Enzyme Inhib Med Chem 2008;23:94-100.

10 Zdrazil B, Schwanke A, Schmitz B, SchäferKorting M, Höltje HD: Molecular modelling studies of new potential human DNA polymerase alpha inhibitors. J Enzyme Inhib Med Chem 2011;26:270-279.

11 Schwanke A, Murruzzu C, Zdrazil B, Zuhse R, Natek M, Höltje M, Korting HC, Reissig HU, Höltje HD, Schäfer-Korting M: Antitumor effects of guanosine-analog phosphonates identified by molecular modelling. Int J Pharm 2010;397:9-18.

12 Tralau T, Riebeling C, Pirow R, Oelgeschlager M, Seiler A, Liebsch M, Luch A: Wind of change challenges toxicological regulators. Environ Health Perspect 2012;120:1489-1494.

13 Arkenau HT, Plummer R, Molife LR, Olmos D, Yap TA, Squires M, Lewis S, Lock V, Yule M, Lyons J, Calvert H, Judson I: A phase I dose escalation study of AT9283, a small molecule inhibitor of aurora kinases, in patients with advanced solid malignancies. Ann Oncol 2012;23:1307-1313.
14 Kramer G, Schwarz S, Hagg M, Havelka AM, Linder S: Docetaxel induces apoptosis in hormone refractory prostate carcinomas during multiple treatment cycles. Br J Cancer 2006; 94:1592-1598.

15 Schäfer-Korting M, Höltje M, Korting HC, Höltje HD: Innovative agents for actinic keratosis and nanocarriers enhancing skin penetration. Skin Pharmacol Physiol 2010;23:6-14.

- 16 Baroli B: Penetration of nanoparticles and nanomaterials in the skin: fiction or reality? J Pharm Sci 2010;99:21-50.

17 Souto EB, Müller RH: Lipid nanoparticles: effect on bioavailability and pharmacokinetic changes; in Schäfer-Korting M (ed): Handbook of Experimental Pharmacology. Heidelberg, Springer, 2010, vol 197: Drug delivery, pp 115-141.

18 Chen H, Chang X, Du D, Liu W, Liu J, Weng T, Yang Y, Xu H, Yang X: Podophyllotoxinloaded solid lipid nanoparticles for epidermal targeting. J Control Release 2006;110:296-306.

19 Santos Maia C, Mehnert W, Schaller M, Korting HC, Gysler A, Haberland A, SchäferKorting M: Drug targeting by solid lipid nanoparticles for dermal use. J Drug Targeting 2002;10:489-495.

20 Stecova J, Mehnert W, Blaschke T, Kleuser B, Sivaramakrishnan R, Zouboulis CC, Seltmann H, Korting HC, Kramer KD, SchäferKorting M: Cyproterone acetate loading to lipid nanoparticles for topical acne treatment: particle characterisation and skin uptake. Pharm Res 2007;24:991-1000.

-21 Hoeller D, Huppertz B, Roos TC, Poblete Gutierrez P, Merk HF, Frank J, Jugert FK: An improved and rapid method to construct skin equivalents from human hair follicles and fibroblasts. Exp Dermatol 2001;10:264-271.
In vitro Efficacy of a Novel Guanosine Phosphonate Analogue
Skin Pharmacol Physiol 2014;27:173-180 DOI: $10.1159 / 000354118$ 
-22 Hoeller Obrigkeit DH, Jugert FK, Beermann T, Baron JM, Frank J, Merk HF, Bickers DR, Abuzahra F: Effects of photodynamic therapy evaluated in a novel three-dimensional squamous cell carcinoma organ construct of the skin. Photochem Photobiol 2009;85:272-278.

-23 Braem C, Blaschke T, Panek-Minkin G, Herrmann W, Schlupp P, Paepenmuller T, MüllerGoyman C, Mehnert W, Bittl R, SchäferKorting M, Kramer KD: Interaction of drug molecules with carrier systems as studied by parelectric spectroscopy and electron spin resonance. J Control Release 2007;119:128135.

24 Freitas C, Müller RH: Correlation between long-term stability of solid lipid nanoparticles (SLN) and crystallinity of the lipid phase. Eur J Pharm Biopharm 1999;47:125-132.

25 Blaschke T, Kankate L, Kramer KD: Structure and dynamics of drug-carrier systems as studied by parelectric spectroscopy. Adv Drug Deliv Rev 2007;59:403-410.

26 Lombardi Borgia S, Regehly M, Sivaramakrishnan R, Mehnert W, Korting HC, Danker K, Röder B, Kramer KD, Schäfer-Korting M: Lipid nanoparticles for skin penetration enhancement - correlation to drug localization within the particle matrix as determined by fluorescence and parelectric spectroscopy. J Control Release 2005;110:151-163.
27 Schäfer-Korting M, Bock U, Diembeck W, Dusing HJ, Gamer A, Haltner-Ukomadu E, Hoffmann C, Kaca M, Kamp H, Kersen S, Kietzmann M, Korting HC, Krächter HU, Lehr CM, Liebsch M, Mehling A, MüllerGoymann C, Netzlaff F, Niedorf F, Rübbelke MK, Schäfer U, Schmidt E, Schreiber S, Spielmann H, Vuia A, Weimer M: The use of reconstructed human epidermis for skin absorption testing: results of the validation study. Altern Lab Anim 2008;36:161-187.

28 ICH: Validation of analytical procedures methodology. ICH Q2B Guideline, 1995.

29 Higuchi WI: Analysis of data on the medicament release from ointments. J Pharm Sci 1962;51:802-804.

30 Commandeur S, van Drongelen V, de Gruijl FR, El Ghalbzouri A: Epidermal growth factor receptor activation and inhibition in $3 \mathrm{D}$ in vitro models of normal skin and human cutaneous squamous cell carcinoma. Cancer Sci 2012;103:2120-2126.

- 31 Gibson VB, Benson RA, Bryson KJ, McInnes IB, Rush CM, Grassia G, Maffia P, Jenkinson EJ, White AJ, Anderson G, Brewer JM, Garside P: A novel method to allow noninvasive, longitudinal imaging of the murine immune system in vivo. Blood 2012;119:2545-2551.

32 Ustaalioglu BB, Bilici A, Ercan S, Seker M, Orcun A, Gumus M: The prognostic importance of changing serum M30 and M65 values after chemotherapy in patients with advancedstage non-small-cell lung cancer. Med Oncol 2013;30:551.

- 33 Ozturk B, Coskun U, Sancak B, Yaman E, Buyukberber S, Benekli M: Elevated serum levels of M30 and M65 in patients with locally advanced head and neck tumors. Int Immunopharmacol 2009;9:645-648.
34 Weng YR, Cui Y, Fang JY: Biological functions of cytokeratin 18 in cancer. Mol Cancer Res 2012;10:485-493.

35 Ari F, Celikler S, Oran S, Balikci N, Ozturk S, Ozel MZ, Ozyurt D, Ulukaya E: Genotoxic, cytotoxic, and apoptotic effects of Hypogymnia physodes (L.) Nyl. on breast cancer cells. Environ Toxicol, E-pub ahead of print.

36 Schlupp P, Blaschke T, Kramer KD, Höltje HD, Mehnert W, Schäfer-Korting M: Drug release and skin penetration from solid lipid nanoparticles and a base cream: a systematic approach from a comparison of three glucocorticoids. Skin Pharmacol Physiol 2011;24: 199-209.

- 37 Küchler S, Wolf NB, Heilmann S, Weindl G, Helfmann J, Yahya MM, Stein C, SchäferKorting M: 3D-wound healing model: influence of morphine and solid lipid nanoparticles. J Biotechnol 2010;148:24-30.

38 Wolf NB, Küchler S, Radowski MR, Blaschke T, Kramer KD, Weindl G, Kleuser B, Haag R, Schäfer-Korting M: Influences of opioids and nanoparticles on in vitro wound healing models. Eur J Pharm Biopharm 2009;73:3442.

39 Atrux-Tallau N, Romagny C, Padois K, Denis A, Haftek M, Falson F, Pirot F, Maibach HI: Effects of glycerol on human skin damaged by acute sodium lauryl sulphate treatment. Arch Dermatol Res 2010;302:435-441.

40 Korting HC, Schäfer-Korting M: Carriers in the topical treatment of skin disease; in Schäfer-Korting M (ed): Handbook of Experimental Pharmacology. Heidelberg, Springer, 2010, vol 197: Drug delivery, pp 435-468. 